\title{
Can We Secure Future-Responsive Management Through Systems Thinking and Design?
}

\author{
WERNER ULRICH \\ Honorary Visiting Professor \\ The Open University, Milton Keynes, United Kingdom
}

\begin{abstract}
Future-responsive management raises far-reaching cognitive and methodological difficulties. This essay in honor of C.W. Churchman, former management scientist and research philosopher at the University of California, Berkeley, analyzes some of these difficulties in the light of Churchman's systems thinking about planning and management. Although systems thinking cannot make the difficulties in question disappear, it can help us to better understand them and to face them self-critically. To this end, the systems idea has more to contribute than is generally recognized. The paper suggests some basic elements of a critical systems ethics yet to be developed.
\end{abstract}

KEY WORDS: C. West Churchman - a personal appreciation; philosophy of the systems approach; management philosophy; environmental ethics; professional practice

Essay history: This is a revised prepublication version of an essay written in celebration of West Churchman's 80th birthday, titled "Can we secure future-responsive management through systems thinking and design?" and originally published in Interfaces, 24, No. 4, 1994, Special Section in Celebration of C.W. Churchman's 80 years, ed. by E. Koenigsberg and J.P. van Gigch, pp. 26-37. (c) 1994 The Institute of Operations Research and the Management Sciences (INFORMS), Hanover, MD [ISSN 0092-2102].

A short version of this essay has been republished in The Environmental Responsibility Reader, ed. by M. Reynolds, C. Blackmore, and M.J. Smith, London-New York: Zed Books, 2009, pp. 132137. [ISBN 978-1-84813-317-4]
The present on-line version is the second revision of the original essay, completed 20 March 2009. The previous revision, which was the first on-line version, was of 12 November 2002. Personal, non-commercial use is permitted on the condition that full credit is given to the source. Quotes must be accompanied by exact page references taken from the original publication or the present PDF version.

Suggested citation: Ulrich, W. (1994). Can we secure future-responsive management through systems thinking and design? Interfaces, 24, No. 4, pp. 26-37. Rev. version, 20 March 2009, in: "A Tribute to C.W. Churchman," Werner Ulrich's Home Page, http://wulrich.com/frm.html and http://wulrich.com/downloads/ulrich_1994.pdf 
A Word of Caution: In the past, some commentators have quoted from earlier versions of this essay as if it represented the original voice of Churchman. This is a misreading of my intent. Rather than aiming at a scholarly exegesis of West's work, I try to honor West by explaining the way I understand his thinking in my work on critical systems heuristics. As much as my work owes to West's influence and inspiration, critical heuristics is different in orientation and language from Churchman's systems approach; it is shaped by the contemporary revival, in Continental Europe, of practical philosophy, language analysis, and discourse theory, and by my subsequent effort to reconstruct the "systems approach" in the terms of practical reason and critical discourse. Please do not blur these differences. Take this essay in the spirit in which I offer it, as a personal appreciation but certainly not as a shortcut to West's ideas, that is, to using or even quoting them without the indispensable effort of reading the original texts. Thank you.

\section{Management as the Art of Designing Improvement}

C. West Churchman is a management scientist of a rare sort. Management to him means more than it usually does in management science (allocation of resources); it means a philosophical challenge to our capabilities of understanding the ethics of whole systems.

Why ethics? Why whole systems? The essence of management is decision making; the hallmark of good decisions is that they promote some kind of desired improvement. But what constitutes an improvement? The concept raises fundamental epistemological and ethical issues. These issues are important to future-responsive management.

\section{The Epistemological Crux: Comprehensiveness}

How can we design improvement without appreciating the totality of conditions that will determine the quality of our decisions, for example, risks and chances, future opportunities, and expected distributions of different benefits and costs? In Churchman's (1968, p. 3) words, "How can we design improvement without understanding the whole system?" To Churchman, the question implies that conventional analytic patterns of decision making and problem solving need to be complemented by a "sweep-in" process (Singer, 1957; Churchman, 1982, pp. 117 and 125-132), a systematic and self-critical attempt to consider ever more aspects of the larger system - ideally, the totality of relevant conditions.

\section{"How can we design improvement without understanding the whole system?"}

Churchman has frequently illustrated the necessity of the process with the example of the inventory problem (1971, pp. 165-167; 1979, p. 45f; 1982, pp. 12-15 and 130-132; see also Mason, 1988, pp. 370-373, and Ulrich, 1998b, pp. 418-421). As Churchman demonstrates, it is quite impossible to design an optimal inventory policy for a manufacturing plant without considering all conceivable alternatives to holding an inventory. The best of the forgone opportunities represents an inventory policy's opportunity costs. How can we reasonably judge the degree to which an inventory policy is sound 
without knowing its opportunity costs? Any estimation of these opportunity costs bursts the definition of the inventory problem and requires us to investigate the larger system of the firm's opportunities. As the relatively simple inventory problem shows, we cannot rationally design improvement without assuming some theory about the nature of the total relevant system.

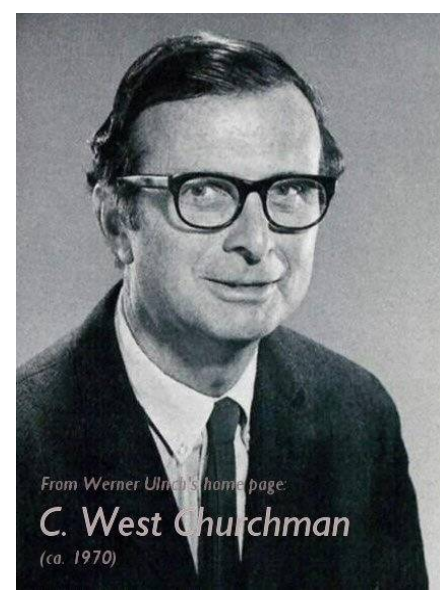

It is obvious that the cognitive requirements of such a quest for comprehensiveness are enormous. It is one of the distinguishing characteristics of Churchman's work that he faces these requirements without taking refuge in any of the conventions of science that so often conveniently shelter theorists from the epistemological implications of the systems idea, for example, the conventions of bounded rationality and satisficing (Simon 1945, 1957, and 1962); of incrementalism (Dahl and Lindblom, 1953); and of piecemeal social engineering (Popper, 1966). Mainstream systems literature somehow always manages to ignore the fact that no conceivable methodology can secure comprehensively rational problem solutions. Most authors seek to demonstrate how and why their systems approaches extend the bounds of rational explanation or design accepted in their fields. Churchman never does. To him, the systems idea challenges us to undertake critical self-reflection. It compels him to question his understanding of problems - and of problem-solving methods but does not tempt him to claim to have the answers. His way of helping us is to suggest questions, not answers.
Accordingly, for Churchman the crucial task in promoting better decision-making is not to prove ever more analytical tools for solving problems but rather, to develop the tools we lack for systematic reflection and debate about the shortcomings and sources of deception contained in a proposed solution, or in the underlying definition of the problem. This is the task that Churchman seeks to accomplish with his dialectical systems approach, which is in noteworthy distinction to the usual problemsolving stance of applied scientists (for further discussion, see Ulrich, 1980 and 1988a).

\section{The Ethical Crux: Conflict}

Once we begin to understand management as the art of designing improvement, we can hardly escape the question of what really constitutes an improvement, that is, what ought to be our standards of improvement. Even if the epistemological challenge could be met satisfactorily, so that some kind of holistic understanding of the world we live in were possible, improvement would hardly ever mean improvement for everyone concerned or affected. Management inescapably implies judgment about whose needs are to be served and what costs are to be imposed on those who are not served but are affected. How can we justify the value implications of decisions in the face of conflicting values, needs and interests? And if we cannot ultimately justify them, what is the meaning of good (or rational) decision-making?

The question is frequently considered to be of little relevance to applied science, as its business is understood to be one of securing the choice of efficient means for given ends. Thus management science is expected to apply rigor to the problem of optimal allocation of resources while referring the selection of ends to those who have the legitimation and power to decide. More than any other author in the fields of management science, 
operations research, and systems thinking, Churchman has admonished us that this kind of answer is inadequate.

It is true, the original intent underlying this separation of the choice of means from the choice of ends is a self-critical one: science must not misunderstand itself as a source of legitimation for value judgments on adequate ends. Science cannot justify such judgments; hence it must refrain from introducing into its propositions value judgments of its own. The problem with this self-restriction of science is not so much that the question of proper ends remains unanswered but rather, that its self-restriction to instrumental question of the proper use of resources for given ends does not buy as much immunity from value judgments as is generally assumed. The choice of means cannot be kept value-free simply by identifying all value judgments with the choice of ends and then referring the choice of ends to an extra-scientific domain. This becomes clear as soon as we consider the fact that alternative means to reach a given end may have different practical implications for those affected by the measures taken. As an example, different policies to obtain an adequate energy supply for a given region, say by means of fossil or nuclear energy production, will impose different risks and costs to different population groups, including the future generations. That is to say, decisions about means, just like decisions about ends, have a normative content that is in need of both ethical reflection and democratic legitimation.

By its own standards of rigor, management science will have to acknowledge that its propositions burst its methodological framework: the meaning of optimization (or simulation or other modeling approaches to securing improvement) remains unclear, and threatens to become a hidden source of suboptimization, without clear - and valid - standards of improvement. In a world of conflicting values, needs, and interests, the most scarce of all resources in optimization is ethically defensible agreement on the standards of improvement, but no conceivable method of optimization can secure such agreement.

This is why a dialectical systems approach of the kind pursued by Churchman - an approach that does not seek to avoid the problem of the ethics of whole systems - is so fundamental if "normal" management science is to achieve its purpose, even though the two approaches may seem irreconcilably different in their orientation and language.

\section{By its own standards of rigor, management science will have to acknowledge that its propositions burst its methodological framework.}

But now, to the specific idea of a futureresponsive management science. What are the specific difficulties to be considered when the task is to secure improvement in the future? What can we say about these difficulties in light of the previous discussion? What kind of systems approach - and perhaps, of management science — could possibly do justice to these difficulties?

\section{What Is Future-Responsive Management? Three Concerns}

Churchman (1970) once defined operations research as "the securing of improvement in social systems by means of the scientific method," whereby securing mainly referred to implementation. Later, the meaning of securing changed. In recent years, Churchman preferred to characterize his interest in terms of "social systems design, the effort to improve social 
systems through planning" (1982b, p. 129). He explains:

The design of my philosophical life is based on an examination of the following question: is it possible to secure improvement in the human condition by means of the human intellect? The verb "to secure" is (for me) terribly important, because ... problem solving often appears to produce improvement, but the so-called 'solution' often makes matters worse in the larger system (e.g., many food programs of the last century may well have made world-wide starvation even worse than no food programs would have done). The verb "to secure" means that in the larger system over time the improvement persists. (1982, pp. 19-20)

In this last definition, the sweep-in process has been expanded to include the larger system over time; adequate standards of improvement now are to be oriented toward the ideal of improvement that persists. In his understanding of management and planning, Churchman has always shown a strong concern for what more recently - particularly in developmental and environmental studies as well as in future research - has come to be designated the ideal of sustainability.

According to this ideal, we should consider our policies and designs for improvement critically with regard to long-term environmental and developmental implications, so as to make sure that they promote ecologically viable and socioeconomically as well as socioculturally desirable conditions. This idea can usefully be applied to our conceptions of sound (rational) management in the private or in the public sector. If one thinks in the long run, it would be appropriate to speak of "sustainable management" in this context, but the term might be perceived to be a bit provocative and, more important, it might be misunderstood, as the crucial point of reference is not the survival of present conceptions of management but the survival of the planetary ecosystem, along with the perspectives that future generations will inherit from us. For this reason, I prefer to speak of future-responsive management.
I cannot give an adequate rendering of Churchman's ideas about future-responsive management. I will suggest three main concerns that I link to the idea of future-responsive management and discuss these concerns with special regard for some of Churchman's basic ideas.

\section{Concern No. 1: The Difficult Cognitive Requirements of a Predictive Approach to the Future - Toward a Different Kind of Future Discourse}

For the first time in the history of humanity, our technological potential reaches far beyond the forseeable future. The causal scale of our technologies, designs, and policies is no longer matched by the reach of our knowledge and understanding. Yet understanding the long-term implications of our actions and omissions - the way they may affect, for instance, the environmental and social conditions of future generations - appears to be the only way to secure "improvement that persists over time in the larger system." How else can we act responsibly in the face of an uncertain future?

On the other hand, if one doesn't want to assume that we can forecast the future, the sweep-in process seems to become a hopeless undertaking, as much as it appears epistemologically necessary. Need we conclude that if we take the systems idea seriously, we are bound to end up with inaction, if not mental breakdown, and ultimately with a bottomless epistemological and ethical skepticism?

The answer for me is no, although I confess that Churchman's "heroic" stance sometimes leaves me dismayed. It is such a tall order! But I think it is only so long as we try to sweep in the future in terms of a forecasting approach (that is, in terms of empirical science) that the quest for futureresponsive management must remain chimerical. 
Apart from the usual focus on this empiricalpredictive dimension of the future discourse, there are other ways to conceive of futureresponsive management.

\section{Churchman's "heroic" stance sometimes leaves me dismayed.}

By challenging cultural assumptions, we make the sweep-in process meaningful without losing practicability. We can then pursue the quest for comprehensiveness by uncovering alternative contexts of meaning (interpreting "facts") rather than by extending our knowledge in an empiricalpredictive sense (technical scope of forecasting).

No impossible cognitive requirements are involved in such an effort, for it aims not at allencompassing knowledge but only at better (mutual) understanding. That is to say, it requires not so much an unbounded exploration of an ever-growing larger system over time but rather a sincere effort to ensure authentic and unhampered communication.

Unfortunately, Churchman's preferred example of the problem of opportunity costs and his emphasis on the heroic aspects of the sweep-in process appear to have caused many of his readers to understand the process chiefly in terms of empirical science and forecasting, which makes it such a hopeless undertaking. Perhaps this misunderstanding explains why his dialectical systems thinking, although well known, has not reached most management scientists and decision makers. But there is actually no need to limit the sweep-in process to the empirical-predictive dimension of the future discourse, nor is it Churchman's intention to do so.
I believe that Churchman's systems thinking, if applied to the cultural dimension of the future discourse, is apt to promote a different, culturally self-aware kind of future research. I think, for instance, of the systematic place that Churchman (1979) gives to the enemies of the systems approach. Bringing in the enemies - rather than just the experts and perhaps the stakeholders might give quite a different quality to future studies and planning efforts. We might conceive of institutional arrangements that would enable concerned citizens to confront proposed designs with culturally different future visions, or, in Churchman's terms, with alternative kinds of "ideal planning." I also find Ackoff's (1974; 1981) related concepts of idealized design and redesigning the future important in this respect.

Regarding the question of institutional arrangements, we need new arenas of participatory problem unfolding and conflict resolution to cultivate this new kind of future discourse. One such arrangement has been suggested and practically tested by Peter Dienel (1989; 1991) in Germany, namely, a kind of citizen commission or citizens' jury that he calls "planning cell" (Planungszelle, people's planning unit). It has been successfully used for developing citizen reports on technological projects (Bürgergutachten). Using statistical rules for random sampling or other procedures that ensure a representation of different concerns, a government body invites citizens to serve on a committee that examines design proposals and comes up with suggestions for better designs.

If such forms of participatory problem solving are to make a real difference, I think it is important that we help the participants to free themselves from prevailing conceptions of expertise and that we provide them with the tools they need to argue their concerns in an authentic, openly subjective, but nevertheless cogent, way. 
Hence another, third, dimension of the sweep-in process is the critical-emancipatory dimension.

The sweep-in process can generally be understood as a means of rendering the participants more aware of, and more competent to challenge, previously unquestioned (because seemingly natural or given) constraints, for example, with regard to the distribution of benefits and negative consequences of a proposed action, or with regard to the distribution of power and resources, including the access to information, expertise, and skills, among those concerned. Authentic mutual understanding, as fostered by the effort of sweeping in the cultural dimension, does not by itself secure conditions of equal participation (doing justice to all those involved), nor can it guarantee ethically justified consensus (doing justice to all those not involved but potentially affected).

\section{Increased understanding alone does not imply a gain of future-responsiveness.}

The step from understanding to critique is as important as the previous shift from forecasting to understanding, for increased understanding alone does not imply a gain of futureresponsiveness but only an enlarged capacity for control. Whether this enlarged capacity will be used for future-responsive action or instead to further the current dominating concepts of rationality remains open.

The crucial issue in applying the sweep-in process to this critical task is the question of how ordinary citizens can argue their concerns in a cogent way, without depending on special expertise or argumentative skills. In Critical Heuristics (Ulrich, 1983, chapter 5), I tried to demonstrate that the systems idea allows us to develop forms of cogent critical argumentation that are accessible to ordinary citizens. I believe that institutional arrangements such as the planning cell can provide ordinary citizens, and experts and designers, with occasions to train themselves in what I call critically-heuristic debate.

\section{Concern No. 2: The Need for Whole- Systems Ethics - Toward a New Ethic of Future-Responsive Management}

An increased consideration of the cultural dimension of the future discourse, though it may help us to uncover alternative future visions, does not automatically secure improvement in an ethical sense, for it has no way of distinguishing ethically defensible from ethically unacceptable consensus. It is equally clear that a fundamental complementarity (interdependence) exists among the three dimensions of the future discourse I have mentioned (the empirical-predictive, the cultural and the critical-emancipatory dimensions), so that any effort to improve practical decision making from the perspective of one dimension only is bound to have serious shortcomings (consider again the example of the 1925 study of the American Petroleum Institute). Due to this complementarity, future-responsive management cannot altogether dispense with the empirical-predictive dimension, which I will deal with under my Concern No. 3.

Traditional ethics is individualistic and volitional in its outlook, that is, it relies on the moral conscience and judgment of individual agents. It identifies moral action with individually good action: the moral quality of an action is taken to be measurable either by an agent's good will, as in Kant's $(1786 ; 1788)$ ethics of duty, or by his or her assuming personal responsibility for those who may be affected by the action, as in Max Weber's (1973) ethics of responsibility. To my knowledge, West Churchman is the first 
philosopher who has seen very clearly the systems-theoretical deficiency of this approach to ethics: it cannot secure improvement, for the measure of improvement must be applied to the whole system. We cannot understand individual morality without understanding the total relevant system that is to serve as a point of reference for defining improvement!

Individualistic ethics originally had its merits, of course: it was apt to keep the cognitive requirements of moral judgment low. It assumed that the consequences of an action were largely forseeable and unequivocal to an agent of good will, as they occurred within a time horizon and a geographical space (and normally also a social life-world) that were shared by the agent and those affected. Accordingly, every agent could be assumed to be able to judge the moral quality of his or her actions. Even in the awakening age of the Enlightenment, Kant could thus still declare a good will to be a sufficient requirement for moral judgment.

But things have changed. Today, good will and good judgment no longer converge so easily. The causal scale of our actions has extended to include world-wide connected socioeconomic processes (for example, economic recession, unemployment, and poverty), long-term social costs that may be imposed on future generations (for example, the health risks of radioactive wastes), and complex and irreversible environmental effects that threaten the survival of the global ecosphere (for example, the greenhouse effect).
That is to say, one now often needs extensive knowledge to anticipate and assess an action's impacts. The once clear-cut boundary between ethics and expertise has become blurred and difficult to draw. An adequate "ethics of an endangered future" (Jonas, 1976) must adapt to this situation. Ethics can no longer be kept knowledge-free, as it were. Quite the contrary, the old moral duty of sustaining a moral conscience (a good will) has been superseded by a new moral duty of being knowledgeable, in the sense that the scale of our designs and that of our knowledge must match.

\section{Things have changed. Today, good will and good judgment no longer converge so easily.}

This new moral duty of being knowledgeable is further complicated by the insight that those who cannot speak for themselves, because they are not yet born (the future generations) or are otherwise handicapped (for example, the fauna and flora of whole ecosystems), must be part of the community of concerned parties considered. A future-responsive ethics must consider the harm or improvement caused in the whole system.

Churchman's concept of a whole systems ethics is apt in this context, as it reminds us of the intrinsic connection between ethical and systems thinking.

Table 1 contrasts some of the mentioned limitations of the old ethics with the requirements of a new, future-responsive ethics: 


\begin{tabular}{|c|c|c|}
\hline Aspect & Old ethics & New ethics \\
\hline $\begin{array}{l}\text { Focus (object of } \\
\text { ethical judgment) }\end{array}$ & $\begin{array}{l}\text { Individualistic ethics: The moral } \\
\text { quality of an agent's individual action } \\
\text { is evaluated. }\end{array}$ & $\begin{array}{l}\text { Whole systems ethics: The improvement of } \\
\text { the whole system is evaluated. }\end{array}$ \\
\hline $\begin{array}{l}\text { Critical instance of } \\
\text { ethical judgment }\end{array}$ & $\begin{array}{l}\text { Volitional ethics: Good will and } \\
\text { personal responsibility („,conscience“) } \\
\text { are the crucial issues of moral } \\
\text { competence. }\end{array}$ & $\begin{array}{l}\text { Cognitivist ethics: Understanding based on } \\
\text { knowledge („con scientia“) of the total } \\
\text { relevant system is the crucial issue of moral } \\
\text { competence. }\end{array}$ \\
\hline $\begin{array}{l}\text { Cognitive } \\
\text { requirements }\end{array}$ & $\begin{array}{l}\text { Low cognitive requirements: can be } \\
\text { met by all people of good will without } \\
\text { requiring any special expertise } \\
\text { (,,knowledge-free“ ethics of certainty). }\end{array}$ & $\begin{array}{l}\text { High cognitive requirements: A sweep-in } \\
\text { process is needed to appreciate the whole- } \\
\text { systems implications of an action from } \\
\text { different viewpoints; collective expertise is } \\
\text { required (Knowledge-based ethics of } \\
\text { uncertainty). }\end{array}$ \\
\hline $\begin{array}{l}\text { Reach with respect } \\
\text { to the future }\end{array}$ & $\begin{array}{l}\text { Ethics of immediacy: The } \\
\text { consequences of an action can be } \\
\text { known and judged from experience, as } \\
\text { the agent and those affected or } \\
\text { concerned share a present, } \\
\text { geographical space and social life- } \\
\text { world. }\end{array}$ & $\begin{array}{l}\text { Ethics of remoteness: The consequences of } \\
\text { an action may not be known from experience; } \\
\text { the agent and those affected or concerned } \\
\text { need not share a present, geographical space } \\
\text { and social life-world. }\end{array}$ \\
\hline $\begin{array}{l}\text { Reach with respect } \\
\text { to environmental } \\
\text { concerns }\end{array}$ & $\begin{array}{l}\text { Anthropocentric ethics: Nature is not } \\
\text { an object of human responsibility, it is } \\
\text { beyond the reach of human } \\
\text { intervention and cares for itself. }\end{array}$ & $\begin{array}{l}\text { Universal ethics: Nature has become an } \\
\text { object of human responsibility, as the causal } \\
\text { scale of our policies and technologies has } \\
\text { become global. }\end{array}$ \\
\hline
\end{tabular}

Table 1: The old ethics are based on the notion that the acting individual can judge the moral quality of his or her action from experience (,,conscience“) while in the new ethics, understanding the whole system (acting „con sciencia“) becomes a crucial moral requirement.

A future-responsive ethics can no longer be a volitional ethics but must be understood in terms of a cognitivist ethics; it will raise epistemological difficulties similar to those of the sweep-in process. The implication, then, appears to be a new moral skepticism. The difficulty is not the systems idea but rather the expanding connectedness of the world in which we live. Corresponding to our previous conclusions regarding the empirical-predictive dimension of the future discourse, we need new strategies for reducing the cognitive requirements of a futureresponsive ethics. We must find ways to render ordinary men and women once again capable of adequate moral judgment. One way toward this goal might consist in a critical turn in ethics, that is, a critical systems ethics. 
From this perspective, the question is not so much whether our ethics are whole systems ethics but rather whether they are critically oriented ethics: unless we are willing to accept moral skepticism, the critical path alone is open. Hence I suggest that in marked contrast to almost all previous ethical theorizing, we renounce the "positive" goal of establishing binding moral justifications in favor of a systematic focus on the critical task of ethics, namely, of methodically identifying and discussing deficits of moral justification. I have elsewhere (Ulrich, 1990) discussed this idea extensively and concluded that systems-theoretical reasoning may provide a key to this task; here I will simply advance the idea of a critical turn of our understanding of the systems approach in general.

\section{Concern No. 3: The Need for a Self- limiting Concept of Systems Rationality - Toward a Critical Turn in Systems Thinking and Design}

Because of the new moral duty of being knowledgeable, and the complementarity of the three dimensions of the future discourse, futureresponsive management cannot altogether dispense with the empirical-predictive dimension. We need additional strategies for reducing the cognitive requirements of future-responsive management.

Otherwise, the quest for future-responsive systems design becomes either critically untenable or else impracticable - critically untenable in the sense of implying an untenable presumption of knowledge, impracticable in the sense of exceeding the cognitive skills of ordinary planners and citizens.

A critical turn of our understanding of systems rationality is in order. In The Systems Approach and Its Enemies, Churchman (1979) taught us essential lessons about such a critical turn.

I understand the book's basic message thus: The concept of systems rationality that will help us to secure improvement is one that clearly acknowledges its own lack of comprehensiveness as a necessary condition of critically tenable practice.

This notion of a nonrationalistic, because selflimiting, concept of rationality for me marks an important turning point in the recent history of systems theory: it represents a shift from "precritical" hard and soft systems thinking to critical systems thinking. From this new perspective, the implication of the systems idea is not that we must understand the whole system but rather that we need to deal critically with the fact that we never do.

\section{A critical turn of our understanding of systems rationality is in order.}

As I tried to show in Critical Heuristics, the systems idea, once we begin to understand it in this sense, will remind us of the un(w)holy character of our systems maps and designs. It can also provide a methodological basis for developing tools of critical reflection conceptual tools that can help us systematically to uncover the inevitable incomprehensiveness or selectivity of designs.

To this end, critical systems heuristics offers both a conceptual framework and forms of cogent argumentation. To the conceptual framework belong some basic critically-heuristic ideas and pragmatic mapping categories (1983, pp. 244$264)$ as well as a checklist of boundary questions (1987, p. 279f; 1993, pp. 596-598; 2000, pp. 255-258); to the forms of argumentation 
belong a basic model of purposeful systems assessment (1983, p. 341f), the process of unfolding (1983, chapter 5; operationalized in 1988b, p. 426f), and the emancipatory (or "polemical") employment of boundary judgments (1983, pp. 305-310; 1993, 599-603; 2000, pp. 257-260). (For introductory overviews see Ulrich, 1987 and 1993.)

The critical turn, and specifically the development of an operational framework for critically-heuristic debate on the shortcomings and implications of systems designs, is far from being accomplished. I hope that others will join me in this effort. Let us put the systems idea to work on the job of dealing rationally with everyday conditions of imperfect rationality, rather than dreaming the impossible dream of comprehensive rationality.

\section{Conclusion}

Can we secure future-responsive management through systems thinking and design? The answer, it seems to me, must be a self-critical „,no," followed by a challenging ,however.“

No, because the systems idea, by helping us to better understand the crucial epistemological and ethical difficulties of securing improvement that persists, does not automatically remove these difficulties. The difficulties in question - the epistemological necessity of the quest for comprehensiveness, the ethical problem of dealing with conflicts of interests, and the subsequent methodological difficulty of defining clear and valid standards of improvement - are not introduced by the systems approach but reflect genuine qualities of the world we live in, in which complex interconnections and conflicts are typical. The idea of future-responsive management raises these difficulties in a particularly acute form, by facing us with the impossible cognitive requirements of an empirical-predictive future discourse and with difficult ethical conflicts between the interests of future and present generations.

However, skepticism provides no solution. It merely serves to immunize mistaken claims to rationality against critical debate. The fact that reason cannot secure comprehensive rationality provides no sound argument against a systematic effort to promote critical awareness with respect to our failure to be comprehensively rational. In particular, it will not help to reject the systems idea because of its difficult implications, as if it caused the difficulties of which it reminds us. The systems idea is neither the cause nor the solution of the problem, it is only the messenger. Accusing the messenger of the bad news will help as little as ignoring the news.

The only reasonable response is to take the messenger seriously and to listen carefully to what it has to say, so as to understand its message as well as possible. To the extent that we take the systems idea seriously, we will begin to understand its critical implications and will thereby gain awareness of our failure to be comprehensive.

Such awareness may ultimately be the only method available for ordinary planners and decision makers to become more futureresponsive. Uncovering the lack of comprehensiveness - the unavoidable selectivity — of our designs, and then systematically tracing the practical implications of that selectivity, is perhaps the only way to prevent the difficulties in question from becoming a source of systematic deception. For me, this is the basic message West Churchman has been teaching us his whole life - a message we have just begun to take seriously. 


\section{References}

Ackoff, R.L. (1974). Redesigning the Future: A Systems Approach to Societal Problems. New York: Wiley.

Ackoff, R.L. (1981). Creating the Corporate Future. New York: Wiley.

Churchman, C.W. (1968). Challenge to Reason. New York: McGraw-Hill.

Churchman, C.W. (1970). Operations research as a profession. Management Science, 17, No. 2, pp. B37B53.

Churchman, C.W. (1971). The Design of Inquiring Systems. New York: Basic Books.

Churchman, C.W. (1979). The Systems Approach and Its Enemies. New York: Basic Books.

Churchman, C.W. (1982). Thought and Wisdom. Seaside, CA: Intersystems Publications.

Dahl, R.A., and Lindblom, C.E. (1953). Politics, Economics and Welfare. New York: Harper (2nd ed., 1976).

Dienel, P.C. (1989). Contributing to social decision methodology: citizen reports on technological projects. In C. Vlek and G. Cvetkovich (eds.), Social Decision Methodology for Technological Projects, Dordrecht, Netherlands: Kluwer, pp. 133-151.

Dienel, P.C. (1991). Die Planungszelle: Der Bürger plant seine Umwelt - Eine Alternative zur EstablishmentDemokratie. 2nd ed. (orig. 1977), Opladen, Germany: Westdeutscher Verlag.

Jonas, H. (1976). Responsibility today: the ethics of an endangered future. Social Research, 43, No. 1, pp. 7797.

Kant, I. (1786). Groundwork of the Metaphysic of Morals, transl. by H.J. Paton. New York: Harper Torchbooks, 1964.

Kant, I. (1788). Critique of Practical Reason And Other Writings in Moral Philosophy, transl. by L.W. Beck. Chicago, IL: University of Chicago Press, 1949.

Mason, R. O. (1988). Exploration of opportunity costs and consideration of future generations: two lasting contributions to systems thinking. Systems Practice, 1, No. 4 (Special Issue: C. West Churchman - 75 Years, ed. by W. Ulrich), pp. 367-375.

Popper, K.R. (1966). The Open Society and Its Enemies. 2 vols., 5th ed., Princeton, NJ: Princeton University Press.

Simon, H.A. (1945). Administrative Behavior. New York: Free Press.

Simon, H.A. (1957). Models of Man. New York: Wiley.

Simon, H.A. (1962). The architecture of complexity. Proceedings of the American Philosophical Society, 106, No. 6, pp. 467-482.

Singer, E.A., Jr. (1957). Experience and Reflection, ed. by C.W. Churchman. Philadelphia, PA: University of Pennsylvania Press.
Ulrich, W. (1980): The metaphysics of design: a SimonChurchman 'debate. Interfaces, 10, No. 2, pp. 35-40. Reprinted in a slightly expanded version under the title "The metaphysics of social systems design" in J.P. van Gigch (ed.), Decision Making About Decision Making: Metamodels and Metasystems, Cambridge, MA, and Tunbridge Wells, UK: Abacus Press, 1987, pp. 219-226.

Ulrich, W. (1983). Critical Heuristics of Social Planning: A New Approach to Practical Philosophy. Bern, Switzerland, and Stuttgart, Germany: Paul Haupt Academic Publishers (pb. reprint ed., Chichester, UK: Wiley, 1994).

Ulrich, W. (1987). Critical heuristics of social systems design. European Journal of Operational Research, 31, No. 3, pp. 276-283.

Ulrich, W. (1988a). C. West Churchman - 75 years, Guest Editorial. Systems Practice, 1, No. 4 (Special Issue: C. West Churchman -75 Years, ed. by W. Ulrich), pp. 341-350.

Ulrich, W. (1988b). Churchman's process of unfolding its significance for policy analysis and evaluation. Systems Practice, 1, No. 4 (Special Issue: C. West Churchman - 75 Years, ed. by W. Ulrich), pp. 415428 .

Ulrich, W. (1990). Critical systems thinking and ethics: the role of contemporary practical philosophy for developing an ethics of whole systems. In B.H. Banathy and B.A. Banathy (eds.), Toward a Just Society for Future Generations, Proceedings of the Thirty-Fourth Annual Meeting of the International Society for the Systems Sciences (ISSS) in Portland, Oregon, July 8-13, 1990, Vol. I, Pomona, CA: ISSS/College of Science, California State Polytechnic University, pp. 52-75.

Ulrich, W. (1993). Some difficulties of ecological thinking considered from a critical systems perspective: a plea for critical holism. Systems Practice, 6, No. 6, pp. 583611

Ulrich, W. (2000). Reflective practice in the civil society: the contribution of critically systemic thinking. Reflective Practice, 1, No. 2, pp. 247-268.

Weber, M. (1973). Politik als Beruf. In J. Winckelmann (ed.), Max Weber, Gesammelte Schriften, 4th ed., Tübingen, Germany: J.C.B. Mohr.

(C) 1993, 2002, 2009 by W. Ulrich Last updated: 12 Dec 2009

Suggested citation: Ulrich, W. (1994). Can we secure futureresponsive management through systems thinking and design? Interfaces, 24, No. 4, pp. 26-37. Rev. version, 20 March 2009, in: "A Tribute to C.W. Churchman," Werner Ulrich's Home Page, http://wulrich.com/frm.html and http://wulrich.com/downloads/ulrich_1994.pdf . 